\title{
Evaluation of the prebiotic potential of arabinoxylans extracted from wheat distillers' dried grains with solubles (DDGS) and in-process samples
}

Article

Accepted Version

Monteagudo, A., Chatzifragkou, A., Kosik, O., Gibson, G., Lovegrove, A., Shewry, P. and Charalampopoulos, D. (2018) Evaluation of the prebiotic potential of arabinoxylans extracted from wheat distillers' dried grains with solubles (DDGS) and inprocess samples. Applied Microbiology and Biotechnology, 102 (17). pp. 7577-7587. ISSN 0175-7598 doi:

https://doi.org/10.1007/s00253-018-9171-6 Available at https://centaur.reading.ac.uk/77773/

It is advisable to refer to the publisher's version if you intend to cite from the work. See Guidance on citing.

To link to this article DOI: http://dx.doi.org/10.1007/s00253-018-9171-6

Publisher: Springer

All outputs in CentAUR are protected by Intellectual Property Rights law, including copyright law. Copyright and IPR is retained by the creators or other copyright holders. Terms and conditions for use of this material are defined in the End User Agreement. 


\section{www.reading.ac.uk/centaur}

\section{CentAUR}

Central Archive at the University of Reading

Reading's research outputs online 


\title{
Evaluation of the prebiotic potential of arabinoxylans extracted from wheat distillers' dried grains with solubles (DDGS) and in-process samples
}

\author{
Andrea Monteagudo-Mera ${ }^{1 *}$, Afroditi Chatzifragkou ${ }^{1}$, Ondrej Kosik ${ }^{2}$, Glenn Gibson ${ }^{1}$, Alison \\ Lovegrove $^{2}$, Peter R. Shewry ${ }^{2}$ and Dimitris Charalampopoulos ${ }^{1}$ \\ ${ }^{1}$ Department of Food and Nutritional Sciences, University of Reading, Whiteknights, PO Box \\ 226, Reading RG6 6AP, UK \\ ${ }^{2}$ Department of Plant Science, Rothamsted Research, Harpenden, AL5 2JQ, Hertfordshire, \\ UK
}

*Corresponding author: email a.monteagudo@reading.ac.uk; Tel. +44 (0) 1183787713 


\begin{abstract}
Distillers' dried grains with solubles (DDGS) is a low value agro-industrial by-product, rich in arabinoxylans (AX), which is produced by commercial distillery and bioethanol plants. In a first approach, we investigated the prebiotic potential of four fractions comprising arabinoxylan oligosaccharides (AXOS) and xylo-oligosaccharides (XOS) obtained by enzymatic hydrolysis of AX fractions derived from DDGS and wet solids (in-process sample of DDGS production process). Anaerobic batch cultures in controlled $\mathrm{pH}$ conditions were used to test the prebiotic activity of the samples. Results did not show significant differences between the enzymatic treatments used and all AXOS/XOS were extensively fermented after $24 \mathrm{~h}$. In addition, significant increases $(\mathrm{P}<0.05)$ in Bifidobacterium and total SCFAs were observed after $24 \mathrm{~h}$ of fermentation. Finally, DDGS-derived hydrolysates were separated on an anionic semi-preparative column to prepare AXOS/XOS fractions with degree of polymerisation (DP) greater than 3. Bifidogenic activity and an increase of SCFAs were again observed after $24 \mathrm{~h}$ of fermentation, although this time the selectivity was higher and the fermentation slower, suggesting that the fermentation of this substrate could take place (at least partially) in the distal part of the colon with highly desirable beneficial effects.
\end{abstract}

\title{
Keywords
}

DDGS, wet solids, arabinoxylooligosaccharides (AXOS), prebiotic, in vitro batch cultures, faecal microbiota 


\section{Introduction}

Gut microbiota plays an important role in the host physiology. Imbalances in the microbiome have been associated with diseases such as inflammatory bowel diseases (IBDs), irritable bowel syndrome (IBS), colorectal cancer or metabolic syndrome (Sobhani et al. 2011; Collins 2014; Festi et al. 2014; Machiels et al. 2014). The composition of the gut microbiota is strongly influenced by different factors including age, host genetics, antibiotic use, immunological factors and diet (Biagi et al. 2010; Zhang et al. 2010; Perez-Cobas et al. 2013; Suzuki and Worobey 2014). Dietary habit is one of the main factors contributing to the diversity of the gut microbiota. In this regard, the consumption of probiotics, prebiotics or the combination of both (synbiotics) is a widely used dietary intervention aimed to beneficially modulate the composition of the intestinal microbiota for the treatment or prevention of gastrointestinal diseases (Wasilewski et al. 2015).

Although both probiotics and prebiotics have high potential for health enhancement and disease prevention, prebiotics have an advantage over probiotics in the lack of viability issues during their commercial storage and gastrointestinal passage. Prebiotics are defined as "a substrate that is selectively utilized by host microorganisms conferring a health benefit" (Gibson et al. 2017). In this regard, the main targeted microorganisms for prebiotics are Bifidobacterium and Lactobacillus species (Gibson 2004). Beneficial physiological effects of prebiotics are associated mainly with the production of Short Chain Fatty Acids (SCFAs) (LeBlanc et al. 2017; Wong et al. 2006) and with the immunological activities resulting from microbiota modulation in the colon (Klaenhammer et al. 2012). Galactooligosaccharides (GOS) and inulin-type fructans are among the most common and extensively studied prebiotics with well demonstrated bifidogenic effects (Vulevic et al. 2015; Vandeputte et al. 2017; Davis et al. 2011). In the last decade, there had been a growing interest in the development of novel prebiotics driven by the increased interest in management of human health through nutrition, especially by the modulation of gut microbiota (Biswal et al. 2017). All the studies carried out on established prebiotics have enabled the better understanding of mechanisms of action and properties, which have provided the basis for emerging prebiotics including a range of plant cell wall polysaccharides (Gullon et al. 2013). The only currently marketed oligosaccharides that are obtained from lignocellulosic biomass are xylooligosaccharides (XOS) (Moniz et al. 2014) with Asian countries being the main producers as their market is still small in Europe and the US. 
XOS are mainly obtained by autohydrolysis of xylans, which consist of a linear backbone of $\beta-(1 \rightarrow 4)$ linked xylose. The xylose units can be either unsubstituted or mono- or disubstituted with $\alpha$-L-arabinofuranosyl (Araf) residues positioned on C-(O)-2 and/or C-(O)-3 positions, forming arabinoxylans (AX) (Saulnier et al. 2007). In addition, xylose residues can be substituted with glucuronic acid or acetyl groups, while arabinose residues can be esterified with phenolic acids, notably ferulic acid. AX constitutes the major polysaccharide in cereal grain cell walls and its hydrolysis with $\beta$-endoxylanase yields a mixture of arabinoxylan oligosaccharides (AXOS) and XOS (Saulnier et al. 2007). Several in vivo and in vitro studies (Francois et al. 2012; Finegold et al. 2014; Gullon et al. 2014) have determined the prebiotic potential of AXOS/XOS fractions showing the enrichment of Bifidobacterium species which have been well documented to promote a number of health benefits for the host (Picard et al. 2005; Russell et al. 2011). Furthermore, XOS/AXOS possess some advantages over other prebiotics already established in the market. For example, XOS exhibit greater resistance to $\mathrm{pH}$ and high temperatures than FOS (Wang et al. 2009) and have been shown to be effective with a lower daily intake (Singh et al. 2015). Distillers' dried grain with solubles (DDGS) is the main by-product of bioethanol and distillery plants and is produced in large amounts annually worldwide. Currently it is principally used as nutrient supplement in livestock feed due to its high content of protein, water soluble vitamins and minerals (Klopfenstein et al. 2008; Schingoethe et al. 2009). Additionally, DDGS is rich in AX and therefore could be a valuable feedstock for AXOS production, increasing the economic value of the by-product as well as contributing to the sustainable development of bioethanol and distillery plants.

In a previous study, we (Chatzifragkou et al. 2016) investigated the extractability of protein from DDGS and in-process samples, such as wet solids (WS), in order to establish potential non-animal feed applications. In the present study, the solid residue of DDGS and WS samples obtained after protein extraction were investigated as a suitable substrate for enzymatic hydrolysis, in order to produce AXOS/XOS. The generated AXOS/XOS fractions were analysed for prebiotic potential, using $\mathrm{pH}-$ controlled anaerobic batch fermentation vessels inoculated with human faecal microbiota to simulate the distal human colonic region. 


\section{Materials and Methods}

\section{Materials}

DDGS and wet solids (WS) were provided by a commercial distillery plant in UK. The samples were lyophilized in a VirTis Bench Top (USA) freeze-drier for $48 \mathrm{~h}$ at $-55^{\circ} \mathrm{C}$ and stored at $-20^{\circ} \mathrm{C}$.

\section{Enzymatic production and purification of AXOS/XOS}

Deproteinised DDGS and WS (Chatzifragkou et al. 2016) were used for the enzymatic production of oligosaccharides. A commercial, food-grade GH11 endo-xylanase $(17 \mathrm{U} / \mathrm{mL}$, Depol 761P, Biocatalysts, Cardiff, Wales, UK) was used solely or in combination with a beta-glucanase with feruloyl esterase side activity, here after referred to as FAE ( $4 \mathrm{U} / \mathrm{mL}$, Depol 740L, Biocatalysts Cardiff, Wales, UK) for the hydrolysis of deproteinised DDGS and WS. These were used as substrates for enzymatic hydrolysis in concentrations of $10 \%(\mathrm{w} / \mathrm{v})$, incubated at $55{ }^{\circ} \mathrm{C}$ for $24 \mathrm{~h}$. Upon completion of the enzymatic reaction, supernatants were collected by centrifugation and analysed for their carbohydrate content. Total carbohydrate content was determined according to (Dubois et al. 1956). The oligosaccharide profile of the hydrolysates was monitored by High-Performance Anion-Exchange Chromatography with Pulsed Amperometric Detection (HPAEC-PAD, Thermo Fisher), on Dionex Carbopac PA1 column ( $10 \mu \mathrm{m}, 4.0 \times 250 \mathrm{~mm})$ (Thermo Scientific, Loughborough, UK). A gradient analysis was carried out using (A) water, (B) $1 \mathrm{M}$ sodium acetate and (C) $0.5 \mathrm{M} \mathrm{NaOH}$ eluents. Running conditions were $0 \min (\mathrm{A}: 80 \%, \mathrm{C}: 20 \%$ ), $30 \min (\mathrm{A}: 63 \%$, B:17\%, C:20\%), $35 \min (\mathrm{A}: 60 \%, \mathrm{~B} \& \mathrm{C}: 20 \%), 40 \min (\mathrm{A}: 57.5 \%$, B:22.5\%, C:20\%), $41 \min (\mathrm{B}: 80 \%, \mathrm{C}: 20 \%)$ and $47 \mathrm{~min}$ up to $65 \mathrm{~min}$ (A:80\%, C:20\%), at a flowrate of $1 \mathrm{~mL} / \mathrm{min}$. Linear xylooligosaccharides up to DP6 were identified using commercially available standards (Megazyme, Bray, Ireland). Substituted or higher DP oligosaccharides were identified according to Kosik et al. (2017), using wheat flour as substrate. Furthermore, enzymatic hydrolysates of DDGS and WS were fractionated by gel filtration, in order to generate fractions with oligosaccharides of DP $\geq 3$. Oligosaccharides were separated on Biogel P2 (Biorad, Hercules, Ca, USA)) column eluted at $3 \mathrm{~mL} / \mathrm{min}$ with deionised water (Tzortzis et al. 2005). A description of all tested DDGS and WS samples is given in Table 1. 


\section{Faecal sample preparation}

Batch culture fermentations were carried out using fresh faecal samples provided by three healthy volunteers (one male, two females; age 24-33 years, omnivores). Donors were free of known metabolic and gastrointestinal diseases and had not received any antibiotic or probiotic treatment for at least 6 months prior to the experiment. Faecal samples were collected in sterile plastic containers which were stored in anaerobic jars containing AnaeroGen sachets (Oxoid, Basingstoke, UK). Stool samples were used within 2 hours of collection. Faecal samples were diluted in sterile phosphate-buffered saline (PBS) and homogenised in filters bags using a stomacher (Stomacher 400, Seward, Worthing, UK) for 4 min to remove large particles. Resulting faecal slurries were used to inoculate the batchculture systems.

\section{In vitro batch cultures}

$100-\mathrm{mL}$ sterile batch fermentation vessels ( $50 \mathrm{~mL}$ working volume) were aseptically filled with $45 \mathrm{~mL}$ of sterile basal nutrient medium and sparged with $\mathrm{O}_{2}$ - free $\mathrm{N}_{2}(15 \mathrm{~mL} / \mathrm{min})$ overnight to establish anaerobic conditions. The basal medium (per litre) consisted of: $2 \mathrm{~g}$ peptone water, $2 \mathrm{~g}$ yeast extract, $0.1 \mathrm{~g} \mathrm{NaCl}, 0.04 \mathrm{~g} \mathrm{~K}_{2} \mathrm{HPO}_{4}, 0.04 \mathrm{~g} \mathrm{KH}_{2} \mathrm{PO}_{4}, 0.01 \mathrm{~g}$ $\mathrm{MgSO}_{4} .7 \mathrm{H}_{2} \mathrm{O}, 0.01 \mathrm{~g} \mathrm{CaCl} 6 \mathrm{H}_{2} \mathrm{O}, 2 \mathrm{~g} \mathrm{NaHCO}_{3}, 2 \mathrm{~mL}$ Tween 80, $0.05 \mathrm{~g}$ hemin, $0.01 \mathrm{~mL}$ vitamin $\mathrm{K} 1,0.5 \mathrm{~g}$ L-cysteine- $\mathrm{HCl}, 0.5 \mathrm{~g}$ bile salt and $4 \mathrm{~mL}$ resazurin solution $(0.25 \mathrm{~g} / \mathrm{L})$. The positive control FOS (Orafti ${ }^{\circledR}$ P95, Beneo, Upton upon Severn, UK) and dried substrates of AXOS/XOS hydrolysates were added $(1 \% \mathrm{w} / \mathrm{v})$ to the respective fermentation vessels just before the addition of the faecal slurry. Vessels were incubated at $37^{\circ} \mathrm{C}$ using a circulating water bath and the $\mathrm{pH}$ was controlled between 6.7 and 6.9 using an automated $\mathrm{pH}$ controller (Fermac 260, Electrolab, Tewkesbury, UK). Each vessel was inoculated with $5 \mathrm{ml}$ of fresh faecal slurry $(1: 10, \mathrm{w} / \mathrm{w})$. Batch cultures were conducted for $24 \mathrm{~h}$, and samples of $3.5 \mathrm{~mL}$ were collected from each vessel at $0,4,8$ and $24 \mathrm{~h}$ for counting of bacterial populations, SCFA analyses and for determining carbohydrate assimilation profiles during fermentation. In a second stage of the study, in order to test the prebiotic activity of AXOS with DP $\geq 3$, $10-\mathrm{mL}$ minibatch vessels were used. In this case, samples were collected at time points of 0 , $8 \mathrm{~h}$ and $24 \mathrm{~h}$, while FOS and a commercial XOS (Longlive Bio-Technology, Shandong, China) product were used as positive controls. The fermentations of purified AXOS with DP 
$\geq 3$ were carried out in duplicate and all the other fermentations in triplicate with different donors.

\section{Lactate and short chain fatty acid analysis}

Samples $(1 \mathrm{~mL})$ taken at each fermentation time point were centrifuged at $13,000 \mathrm{xg}$ for 10 min. Supernatants were filtered through a $0.22 \mu \mathrm{m}$ Millipore syringe filter. HPLC was performed using an Agilent 1100 series HPLC (Hewlett-Packard, Agilent, Bracknell, UK) equipped with a Refractive Index (RI) Detector. The ion-exclusion REZEX-ROA Organic acid column (Phenomenex Inc., Macclesfield, UK) was maintained at a constant temperature of $85{ }^{\circ} \mathrm{C}$. The eluent was sulphuric acid in HPLC water $(0.0025 \mathrm{mmol} / \mathrm{L})$, with a flow rate of $0.5 \mathrm{~mL} / \mathrm{min}$. Calibration curves for lactate, acetate, formate, propionate and butyrate were accomplished for SCFA quantification. The mean metabolite concentrations were expressed as $\mathrm{mM}$.

\section{Flow Cytometry-Fluorescence in situ hybridization}

Collected samples $(750 \mu \mathrm{L})$ were centrifuged at $10,000 \mathrm{xg}$ for $5 \mathrm{~min}$ at room temperature. Pellets were fixed for further fluorescence in situ hybridization and kept at $-20{ }^{\circ} \mathrm{C}$. Briefly, after centrifugation pellets were re-suspended in $375 \mu \mathrm{L}$ of $1 \mathrm{X}$ PBS and 1,125.5 $\mu \mathrm{L}$ of cold 4 $\%(\mathrm{w} / \mathrm{v})$ paraformaldehyde. Suspension was mixed and stored at $4{ }^{\circ} \mathrm{C}$ for $4-6 \mathrm{~h}$. After incubation, samples were washed twice with $1 \mathrm{~mL}$ of 1X PBS. Finally, samples were centrifuged at $10,000 \mathrm{xg}$ for $5 \mathrm{~min}$, the supernatant was discarded and the pellet was resuspended in $300 \mu \mathrm{L}$ of $1 \mathrm{X}$ PBS and $300 \mu \mathrm{L}$ of ethanol. Samples were vortexed and stored at $-20{ }^{\circ} \mathrm{C}$ for further analysis. For Flow-FISH cytometry, the $16 \mathrm{~S}$ ribosomal RNA molecule labelled with the fluorescent was used for the enumeration of bacterial groups (Table 2). $75 \mu \mathrm{L}$ aliquots of the fixed samples were collected from the fixed cell solutions stored at -20 ${ }^{\circ} \mathrm{C}$. The fixed cells were washed twice with PBS and pre-treated for $10 \mathrm{~min}$ with lysozyme at $1 \mathrm{mg} / \mathrm{mL}$. Cells were re-suspended in $1 \mathrm{~mL}$ of hybridization buffer (HB). All hybridizations were performed in the dark at $35{ }^{\circ} \mathrm{C}$ overnight in the hybridization solution containing the appropriate labelled probe (Table 2). Cells were centrifuged at 10,000 $\mathrm{xg}$ for $3 \mathrm{~min}$, resuspended in pre-warmed washing buffer and incubated at $37^{\circ} \mathrm{C}$ for $20 \mathrm{~min}$ to remove nonspecific binding of the probe. Finally, cells were centrifuged at 10,000 xg for $3 \mathrm{~min}$ and resuspended in PBS for flow cytometry analysis. 


\section{Statistical studies}

Statistical analyses were performed using SPSS for Windows, version 21. Univariate analysis of variance and Tukey's posthoc test was used to determine significant changes in the microbiota populations and SCFA concentrations at inoculation and subsequent sampling points and to compare differences in the effects of the different substrates at the same time point. Differences were considered to be significant when $P<0.05$.

\section{Results}

\section{Prebiotic potential of produced AXOS/XOS hydrolysates}

\section{Substrates consumption}

Hydrolysates treated only with endo-xylanase showed initially lower amounts of xylose and xylobiose $(6.06 \% \pm 4.06$ and $2.08 \pm 1.41)$ than samples treated with the combination of the two enzymes (Xylanase and FAE) (15.43 \pm 4.74 and 12.16 \pm 8.03$)$. Supplemental Table S1 shows the AXOS/XOS consumption over the course of fermentation by faecal microbiota. The three donors showed slight variations in magnitude and trends that coincided with higher standard deviations. All substrates were totally consumed between 8 and $24 \mathrm{~h}$ of fermentation. Oligosaccharides obtained from DDGS were almost totally depleted after $8 \mathrm{~h}$ of fermentation in donors 1 and 2 while AXOS/XOS obtained from WS were consumed slower (between 8 and $24 \mathrm{~h}$ of fermentation) (Fig. 1). In donor 3 (data not shown), all substrates (DDGS and WS) were almost totally consumed after $8 \mathrm{~h}$ of fermentation. The different assimilation profiles observed among donors and time points agreed with the growth kinetic of total bacteria. In this regard, the maximum bacterial population was obtained at $8 \mathrm{~h}$ in the case of DDGS substrates and at $24 \mathrm{~h}$ with WS substrates. For donor 3 the maximum bacterial population occurred at $8 \mathrm{~h}$ for both DDGS- and WS- derived oligosaccharides.

\section{Enumeration of specific bacterial populations}

Bacterial group counts during the batch cultures fermentations of the different AXOS substrates are shown in Fig. 2 and Supplemental Table S2. 
Overall, the most notable impact of AXOS/XOS fermentation on the composition of the faecal microbiota was the population growth of Bifidobacterium. AXOS/XOS utilization by faecal microbiota resulted in statistically significant increases $(\mathrm{P}<0.05)$ in Bifidobacterium counts after $24 \mathrm{~h}$ of fermentation for all AXOS/XOS hydrolysates tested (Fig. 2 and Supplemental Table S2). Specifically increases between 1.3-1.7 log were observed at the end of the fermentation (Fig. 2). In addition, DDGS hydrolysates treated with xylanase (DDGSXyl) and wet solid hydrolysates generated with xylanase and feruloyl esterase (WS$\mathrm{Xyl}+\mathrm{FAE}$ ) also increased significantly Bifidobacterium populations after $8 \mathrm{~h}$ of fermentation. Populations of Bacteroides-Prevotella (BAC) and propionate producing bacteria (PROP) were increased by more than 10 -fold between 8 and $24 \mathrm{~h}$ of fermentation with all AXOS/XOS substrates except for DDGS-Xyl+FAE; although significant differences were only observed when WS-Xyl+FAE was used as substrate. The wet solids hydrolysates also increased the growth of bacteria detected by Lab158 (Lactobacillus-Enterococcus group) in more than 10-fold over $24 \mathrm{~h}$ fermentation, but the differences were not significant when compared to time 0 or the negative control. A significant reduction in the population of Faecalibacterium prausnitzii was detected after $8 \mathrm{~h}$ and $24 \mathrm{~h}$ when the FOS (positive control) was used as substrate. No significant changes were detected in any other enumerated bacterial populations (Supplemental Table S2).

\section{Organic acid production in faecal batch cultures}

The production of SCFAs (acetate, formate, propionate and butyrate) and lactate determined during the fermentation in batch cultures. All substrates tested, except DDGS-Xyl+FAE, significantly increased the total SCFA concentrations $(\mathrm{P}<0.05)$ after $8 \mathrm{~h}$ and $24 \mathrm{~h}$ of fermentation (Fig. 3). Acetate was the main SCFA detected during the fermentation of all tested substrates and its production accounted for approximately $65 \%$ of total SCFAs. Significant increases in acetate $(P<0.05)$ were also observed at $8 \mathrm{~h}$ and $24 \mathrm{~h}$ of fermentation with the AXOS substrates, except for DDGS-Xyl+FAE $(P=0.06)$. A significant increase in lactate was also observed at $8 \mathrm{~h}$ of fermentation with all substrates except in WS-Xyl (Supplemental Table S3). During the period 8-24 h, lactate was significantly depleted which is consistent with the fact that this product can be utilised by other groups of bacteria to produce acetate, propionate or butyrate (cross-feeding). 
Substantial increases in the concentration of propionate, the second most abundant SCFA after acetate, and moderate increases in butyrate were also observed after $24 \mathrm{~h}$ (Supplemental Table S3) although no significant differences were observed between the time points because of the variation in responses found between donors. Similarly, no significant differences were found in formic production after $24 \mathrm{~h}$ of fermentation.

\section{Prebiotic potential of purified AXOS/XOS}

Fig. 4 shows the carbohydrate profiles from commercial XOS and purified hydrolysates of AXOS/XOS DP $\geq 3$ obtained from DDGS during fermentation. Commercial XOS were more quickly fermented than AXOS/XOS DP $\geq 3$ where some oligosaccharides were still present at $24 \mathrm{~h}$. Overall, both XOS and AXOS DP $\geq 3$ were broken down without increases in xylose. Counts of all bacterial group during the mini-batch cultures are shown in Supplemental Table S4. The most noticeable change in the microbiota composition in the presence of oligosaccharides was a significant increase of Bifidobacterium numbers (Fig. 5). While commercial XOS and FOS resulted in significant increases in Bifidobacterium at $8 \mathrm{~h}$ and $24 \mathrm{~h}$ of fermentation, the bifidogenic effect of AXOS fractions DP $\geq 3$ was more gradual (Fig. 5). No significant changes were detected in any of the other bacterial populations enumerated. Acetate was the main SCFA detected and represented $60 \%-65 \%$ of total SCFAs. Across all substrates, formate and lactate were transient metabolites reaching maxima at $8 \mathrm{~h}$ (Table 3 ). Different profiles of production of butyrate and propionate were observed between commercial FOS and XOS and AXOS/XOS DP $\geq 3$. FOS and XOS resulted in increases in butyrate after $24 \mathrm{~h}$ which accounted for approximately $12 \%$ of total SCFAs. However, the fermentation of AXOS/XOS DP $\geq 3$ resulted in significantly increased production of propionate and reduction of butyrate levels compared to the fermentation of FOS and XOS after $24 \mathrm{~h}$.

\section{Discussion}

The present study aimed to demonstrate the prebiotic potential of AXOS/XOS derived from wheat DDGS and in-process samples on human faecal microbiota.

The main characteristic of a prebiotic compound is to induce a selective stimulation of beneficial bacteria in the colon microbiota (Gibson et al. 2017). In this regard, the 
Bifidobacterium genus is the most frequent target for prebiotics. Numerous species of Bifidobacterium have been studied and demonstrated as probiotic agents. A range of healthpromoting activities have been described for bifidobacteria in recent years including reduction in serum cholesterol, prevention of colo-rectal cancer, prevention of infectious diarrhoea, modulation of mucosal barrier function and production of amino acids and vitamins (Xiao et al. 2003; D'Aimmo et al. 2012; Zanotti et al. 2015). This study showed that AXOS hydrolysates promoted bifidogenic activity during the fermentation of the substrates. Selectivity of AXOS/XOS substrates for bifidobacteria was observed in the period between 0 and $8 \mathrm{~h}$, where most of the oligosaccharides were consumed. Moderate increases in other groups of bacteria (Bacteroides-Prevotella and Clostridia cluster IX) were detected simultaneously with the significant bifidogenic effect after $8 \mathrm{~h}$ and it is notable that several members of these groups of bacteria have been reported to be able to degrade xylan (Wang et al. 2016; Zhang et al. 2016). However, Bifidobacterium was able to compete more successfully for XOS/AXOS during the first $8 \mathrm{~h}$, demonstrating faster growth than Bacteroides/Prevotella. Additionally, the proliferation of the Clostridium cluster IX after $8 \mathrm{~h}$ could also result from cross feeding using the lactate and acetate generated by Bifidobacterium. A closer examination of the samples donor by donor revealed that in general, the bifidogenic effect was smaller in donor 3. The ability of Bifidobacterium to grow on XOS is reported to be depended on the strain (Riviere et al. 2014) and a different composition of Bifidobacterium in donor 3 could be the responsible factor of this interindividual variation.

SCFAs produced during oligosaccharides fermentation by commensal bacteria in the colon are known to contribute to multiple benefits to the host (Koh et al. 2016). In this study, AXOS increased the production of total SCFAs with the greatest contribution to this increase being the production of acetate. The significant increases in acetate and lactate at $8 \mathrm{~h}$ could relate to the significant growth of the acetate and lactate producing Bifidobacterium group. Although not statistically significant, the increases in butyrate during AXOS fermentation could be related to the increases abundance of the Clostridium IX group which includes several butyrate producers. This would explain why no increases in butyrate were observed with the positive control which did not induce the growth of Clostridium IX groups and significantly reduced the main butyrate producer $F$. prausnitzii after $24 \mathrm{~h}$. Propionate was the second most abundant SCFA produced; its production has been reported to be related with the presence of side chains in xylooligosaccharides (XOS) such as in AXOS (Broekaert et al. 
2011; Gullón et al. 2014) and with increases in the Bacteroides-Prevotella group (Hughes et al. 2008) and Clostridium Cluster IX.

The enzymatic hydrolysis of DDGS and wet solids by endo-xylanases or by the combination of endo-xylanases and FAE enzymes did not result in marked differences in terms of prebiotic activity of the hydrolysates. The mixture of these two enzymes was expected to exert a synergistic action on the hemicellulose polymer of DDGS and WS residues, that would in turn improve the solubilisation of $\mathrm{AX}$ as well as release ferulic acid as a high value co-product. However, the combination of enzymes also resulted in higher amounts of arabinose, xylose (X1) and xylobiose (X2) compared to the hydrolysates generated only by endo-xylanases. The presence of large amounts of monosaccharides and disaccharides in prebiotic products is frequently undesirable since these can be metabolized before reaching the large intestine and hence reducing their ability to stimulate the growth and/or activity of health-promoting bacteria. Therefore, although no statistical differences were observed in our study between the in vitro prebiotic activity of the enzyme treatments, a further study was carried out to purify oligosaccharides of DP $\geq 3$ that are expected to have higher persistence in the intestine. The persistence of prebiotics in the intestine is one of the main aims for prebiotic development. Some chronic diseases, such as ulcerative colitis and colon cancer, frequently start in the distal colon where a more proteolytic environment exists before progressing towards the proximal region, which is characterised by higher saccharolytic activity (Macfarlane et al. 1992). Consequently, prebiotics that reach the distal region of the colon could display an advantage in the prevention of some intestinal diseases. A strategy to achieve this effect is to increase the molecular weight of the prebiotic oligosaccharides. In this regard, AXOS/XOS fractions with DP $\geq 3$ obtained from DDGS showed slower fermentation compared to the commercial XOS and the unfractionated AXOS/XOS hydrolysates that were totally depleted after $24 \mathrm{~h}$ of fermentation. Commercial XOS are composed of xylobiose (35\%) and 60\% total fibre (non-digestible oligomers; $n=3-6$ ) with xylose backbones. The removal of xylobiose and the presence of arabinoxylans in our DDGS-derived hydrolysate appeared to positively influence the utilisation of these carbohydrates by faecal Bifidobacterium. The slow production of SCFAs and the slower growth of Bifidobacterium reflect slower fermentation that could be an indicator of a higher prebiotic selectivity. The multiple side branches present in AXOS compared to commercial FOS or XOS could require more and different enzymes for their hydrolysis, restricting the fermentation of these substrates to less bacterial species. The presence of small amounts of carbohydrates not exhaustively fermented at $24 \mathrm{~h}$ with AXOS/XOS DP $\geq 3$, suggests the 
potential increase in the bifidobacteria population after $24 \mathrm{~h}$. On the other hand, the higher production of propionate during fermentation of AXOS DP $\geq 3$ has been related to the presence of side chains in xylooligosaccharides (XOS) such as those in AXOS (Broekaert et al. 2011; Gullon et al. 2014). This increase of propionate in our study agrees with increases in the populations of propionate producing bacteria such as Clostridium Cluster IX and Bacteroides.

In summary, DDGS and wet solids obtained from distillery plants were successfully used as substrates for the enzymatic production of AXOS/XOS with potential prebiotic activity. The in vitro fermentation of AXOS hydrolysates showed high stimulatory effect on Bifidobacterium. Removal of monosaccharides and disaccharides from these hydrolysates resulted in slower growth of Bifidobacterium and higher propionate concentration than commercial prebiotics such as FOS and XOS. This slower fermentation could be advantageous allowing at least a proportion of the AXOS/XOS to reach the distal part of the colon with beneficial effects on disorders which occur in this region. AXOS/XOS from DDGS could be a promising option to other established prebiotics such as FOS due to the low cost of the material source and easy low-cost extraction methods. Further studies using gut models and human intervention will be required to confirm the prebiotic efficacy of AXOS/XOS obtained from DDGS.

\section{Acknowledgements}

The authors would like to acknowledge the Integrated Biorefining Research and Technology Club (IBTI) of the UK Biotechnology and Biological Sciences Research Council (BBSRC) for their financial support on the research project entitled "Development of a process scheme for the production of high value functional products from DDGS” (BB/J019429/1 University of Reading; BB/J019380/1 - Rothamsted Research). Rothamsted Research receives grant-aided support from the Biotechnology and Biological Sciences Research Council of the UK and the work forms part of the Designing Future Wheat Strategic Program $(\mathrm{BB} / \mathrm{P} 016855 / 1)$.

\section{Compliance with Ethical Standards}

\section{Conflict of Interest}


The authors declare that they have no conflict of interest.

\section{Ethical approval}

This experiment was carried out in triplicate using faecal samples from three different volunteers (one faecal donor for each experimental set up). The study was conducted according to guidelines laid down in the Declaration of Helsinki 1975, as revised in 1983. After obtaining verbal informed consent, a standard questionnaire to collect information regarding the health status, drugs use, clinical anamnesis, and lifestyle was administrated before the donor was ask to provide a faecal sample. All procedures involving human subjects were approved by the Ethics Committee of the University of Reading. 


\section{References}

Biagi E, Nylund L, Candela M, Ostan R, Bucci L, Pini E, Nikkila J, Monti D, Satokari R, Franceschi C, Brigidi P, De Vos W (2010) Through ageing, and beyond: Gut microbiota and inflammatory status in seniors and centenarians. Plos One 5:1-14.

https://doi.org/10.1371/annotation/df45912f-d15c-44ab-8312-e7ec0607604d

Biswal P, Pal A, Das AP (2017) Current trends and future prospective of prebiotics as therapeutic food. In Holban AM, Grumezescu AM (eds) Microbial production of food ingredients and additives, Academic Press London, pp 57-88.

Broekaert WF, Courtin CM, Verbeke K, Van de Wiele T, Verstraete W, Delcour JA. (2011) Prebiotic and other health-related effects of cereal-derived arabinoxylans, arabinoxylanoligosaccharides, and xylooligosaccharides. Crit Rev Food Sci 51:178-194.

Chatzifragkou A, Prabhakumari PC, Kosik O, Lovegrove A, Shewry PR, Charalampopoulos D (2016) Extractability and characteristics of proteins deriving from wheat DDGS. Food Chem 198:12-19.

Collins SM (2014) A role for the gut microbiota in IBS. Nat Rev Gastro Hepat 11:497-505.

D'Aimmo MR, Mattarelli P, Biavati B, Carlsson NG, Andlid T (2012) The potential of bifidobacteria as a source of natural folate. J Appl Microbiol 112:975-984.

Daims H, Bruhl A, Amann R, Schleifer KH, Wagner M (1999) The domain-specific probe EUB338 is insufficient for the detection of all bacteria: Development and evaluation of a more comprehensive probe set. Syst Appl Microbiol 22:434-444.

Davis LMG, Martinez I, Walter J, Goin C, Hutkins RW (2011) Barcoded pyrosequencing reveals that consumption of galactooligosaccharides results in a highly specific bifidogenic response in humans. Plos One 6:1-10 https://doi.org/10.1371/journal.pone.0025200

Devereux R, Kane MD, Winfrey J, Stahl DA (1992) Genus-specific and group-specific hybridization probes for determinative and environmental-studies of sulfate-reducing bacteria. Syst Appl Microbiol 15:601-609.

Dubois M, Gilles K.A, Hamilton JK, Rebers P.A Smith F (1956) Colorimetric method for determination of sugars and related substances. Anal Chem 28:350-356.

Festi D, Schiumerini R, Eusebi LH, Marasco G, Taddia M, Colecchia A (2014) Gut microbiota and metabolic syndrome. World J Gastroentero 20:16079-16094.

Finegold SM, Li ZP, Summanen PH, Downes J, Thames G, Corbett K, Dowd S, Krak M, Heber D (2014) Xylooligosaccharide increases bifidobacteria but not lactobacilli in human gut microbiota. Food Funct 5:436-445.

Francois IEJA, Lescroart O, Veraverbeke WS, Marzorati M, Possemiers S, Evenepoel P, Hamer H, Houben E, Windey K, Welling GW, Delcour JA, Courtin CM, Verbeke K, Broekaert WF (2012) Effects of a wheat bran extract containing arabinoxylan 
oligosaccharides on gastrointestinal health parameters in healthy adult human volunteers: a double-blind, randomised, placebo-controlled, cross-over trial. Brit J Nutr 108:2229-2242.

Franks AH, Harmsen HJM, Raangs GC, Jansen GJ, Schut F, Welling GW (1998) Variations of bacterial populations in human feces measured by fluorescent in situ hybridization with group-specific 16S rRNA-Targeted oligonucleotide probes. Appl Environ Microbiol 64:3336-3345.

Gibson GR (2004) Fibre and effects on probiotics (the prebiotic concept). Clin Nutr 1:25-31.

Gibson GR, Hutkins R, Sanders ME, Prescott SL, Reimer RA, Salminen SJ, Scott K, Stanton C, Swanson KS, Cani PD, Verbeke K, Reid G (2017) Expert consensus document: The international scientific association for probiotics and prebiotics (ISAPP) consensus statement on the definition and scope of prebiotics. Nat Rev Gastroenterol Hepatol 14:491-502.

Gullon B, Gullon P, Tavaria F, Pintado M, Gomes AM, Alonso JL, Parajo JC (2014) Structural features and assessment of prebiotic activity of refined arabinoxylooligosaccharides from wheat bran. J Funct Foods 6:438-449.

Gullon P, Gullon B, Moure A, JL, A, Dominguez H, Parajo JC (2013) Manufacture of prebiotics from biomass sources. In: Charalampopoulos D, Rastall RA (eds) Prebiotics and probiotics science and technology, Springer-Verlag New York, pp 535-589

Harmsen HJ, Elfferich P, Schut F, Welling GW (1999) A 16S rRNA-targeted probe for detection of lactobacilli and enterococci in faecal samples by fluorescent in situ hybridization. Microb Ecol Health Dis 11:3-12.

Harmsen HJ, Wildeboer-Veloo AC, Grijpstra J, Knol J, Degener JE, Welling, GW (2000) Development of 16S rRNA-based probes for the Coriobacterium group and the Atopobium cluster and their application for enumeration of Coriobacteriaceae in human feces from volunteers of different ages. Appl Environ Microbiol 66:4523-4527.

Saulnier L, Sado PE, Branlard G, Charmet G, Guillon F (2007) Wheat arabinoxylans: Exploiting variation in amount and composition to develop enhanced varieties. J Cereal Sci 46:261-281.

Hold GL, Schwiertz A, Aminov RI, Blaut M, Flint HJ (2003) Oligonucleotide probes that detect quantitatively significant groups of butyrate-producing bacteria in human feces. Appl Environ Microbiol 69:4320-4324.

Klaenhammer TR, Kleerebezem M, Kopp MV, Rescigno M (2012) The impact of probiotics and prebiotics on the immune system. Nat Rev Immunol 12:728-734.

Klopfenstein TJ, Erickson GE, Bremer VR (2008) Use of distillers by-products in the beef cattle feeding industry. J Anim Sci 86:1223-1231.

Koh A, De Vadder F, Kovatcheva-Datchary P, Backhed F (2016) From dietary fiber to host physiology: Short-chain fatty acids as key bacterial metabolites. Cell 165:1332-1345. 
Langendijk PS, Schut F, Jansen GJ, Raangs GW, Kamphuis GR, Wilkinson MHF, Welling GW (1995) Quantitative fluorescent in situ hybridisation of Bifidobacterium spp. with genus specific 16S rRNA targeted probes and its application in fecal samples. Appl Environ Microbiol 61:3069-3075.

LeBlanc JG, Chain F, Martín R, Bermúdez-Humarán LG, Courau S, Langella P (2017) Beneficial effects on host energy metabolism of short chain fatty acids and vitamins produced by commensal and probiotic bacteria. Benef Microbes 16:1-10

https://doi.org/10.1186/s12934-017-0691-z

Macfarlane GT, Gibson GR, Cummings JH (1992) Comparison of fermentation reactions in different regions of the human colon. J Appl Bacteriol 72:57-64.

Machiels K, Joossens M, Sabino J, De Preter V, Arijs I, Eeckhaut V, Ballet V, Claes K, Van Immerseel F, Verbeke K, Ferrante M, Verhaegen J, Rutgeerts P, Vermeire S (2014) A decrease of the butyrate-producing species Roseburia hominis and Faecalibacterium prausnitzii defines dysbiosis in patients with ulcerative colitis. Gut 63:1275-1283.

Manz W, Amann R, Ludwig W, Vancanneyt M, Schleifer KH (1996) Application of a suite of 16S rRNA-specific oligonucleotide probes designed to investigate bacteria of the phylum cytophaga-flavobacter-bacteroides in the natural environment. Microbiology 142:1097-1106.

Moniz P, Pereira H, Duarte LC, Carvalheiro F (2014) Hydrothermal production and gel filtration purification of xylo-oligosaccharides from rice straw. Ind Crop Prod 62:460-465.

Perez-Cobas AE, Gosalbes MJ, Friedrichs A, Knecht H, Artacho A, Eismann K, Otto W, Rojo D, Bargiela R, von Bergen M, Neulinger SC, Daumer C, Heinsen FA, Latorre A, Barbas C, Seifert J, dos Santos VM, Ott SJ, Ferrer M, Moya A (2013) Gut microbiota disturbance during antibiotic therapy: a multi-omic approach. Gut 62:1591-1601.

Picard C, Fioramonti J, Francois A, Robinson T, Neant F, Matuchansky C (2005) Review article: bifidobacteria as probiotic agents - physiological effects and clinical benefits. Aliment Pharm Therap 22:495-512.

Riviere A, Moens F, Selak M, Maes D, Weckx S, Vuyst LD (2014) The ability of bifidobacteria to degrade arabinoxylan oligosaccharide constituents and derived oligosaccharides is strain dependent. Appl Environ Microbiol 80:204-217.

Russell DA, Ross RP, Fitzgerald GF, Stanton C (2011) Metabolic activities and probiotic potential of bifidobacteria. Int J Food Microbiol 149:88-105.

Schingoethe DJ, Kalscheur KF, Hippen AR, Garcia AD, (2009) Invited review: The use of distillers products in dairy cattle diets. J Dairy Sci 92:5802-5813.

Singh A, Nisha, Singh P (2015) Formation of amino acids from NH3/NO2, CO2 and H2O: Implications for the prebiotic origin of biomolecules. Rapid Commun Mass Sp 29:20902094. 
Sobhani I, Tap J, Roudot-Thoraval F, Roperch JP, Letulle S, Langella P, Corthier G, Van Nhieu JT, Furet JP (2011) Microbial dysbiosis in colorectal cancer (CRC) Patients. Plos One 6:1-7 https://doi.org/10.1371/journal.pone.0016393

Suzuki TA, Worobey M (2014) Geographical variation of human gut microbial composition. Biol Letters 10:1-5 https://doi.org/10.1098/rsbl.2013.1037

Tzortzis G, Goulas AK, Gee JM, Gibson GR (2005) A novel galactooligosaccharide mixture increases the bifidobacterial population numbers in a continuous in vitro fermentation system and in the proximal colonic contents of pigs in vivo. J Nutr 135:1726-1731.

Vandeputte D, Falony G, Vieira-Silva S, Wang J, Sailer M, Theis S, Verbeke K, Raes J (2017) Prebiotic inulin-type fructans induce specific changes in the human gut microbiota. Gut 66: 1968-1974.

Vulevic J, Juric A, Walton G, Claus S, Tzortzis G, Toward R, Gibson G (2015) Influence of galacto-oligosaccharide mixture (B-GOS) on gut microbiota, immune parameters and metabonomics in elderly persons. Br J Nutr 114: 586-595.

Walker AW, Duncan SH, Leitch, ECMW, Child MW, Flint HJ (2005) pH and peptide supply can radically alter bacterial populations and short-chain fatty acid ratios within microbial communities from the human colon. Appl Environ Microbiol 71:3692-3700.

Wallner G, Amann R, Beisker W (1993) Optimizing fluorescent insitu hybridization with ribosomal-RNA-targeted oligonucleotide probes for flow cytometric identification of microorganisms. Cytometry 14:136-143.

Wang J, Sun BG, Cao YP. Tian, Y. (2009) Enzymatic preparation of wheat bran xylooligosaccharides and their stability during pasteurization and autoclave sterilization at low pH. Carbohyd Polym 77:816-821.

Wang K, Pereira GV, Cavalcante JJV, Zhang ML, Mackie R, Cann I (2016) Bacteroides intestinalis DSM 17393, a member of the human colonic microbiome, upregulates multiple endoxylanases during growth on xylan. Sci Rep 6:1-11 https://doi.org/10.1038/srep34360

Wasilewski A, Zielińska M, Storr M, Fichna J (2015) Beneficial Effects of Probiotics, Prebiotics, Synbiotics, and Psychobiotics in Inflammatory Bowel Disease. Inflamm Bowel Dis 21: 1674-1682.

Wong JMW, de Souza R, Kendall CWC, Emam A, Jenkins DJA (2006) Colonic health: Fermentation and short chain fatty acids. J Clin Gastroenterol 40:235-243.

Xiao JZ, Kondo S, Takahashi N, Miyaji K, Oshida K, Hiramatsu A, Iwatsuki K, Kokubo S, Hosono A (2003) Effects of milk products fermented by Bifidobacterium longum on blood lipids in rats and healthy adult male volunteers. J Dairy Sci 86:2452-2461.

Zanotti I, Turroni F, Piemontese A, Mancabelli L, Milani C, Viappiani A, Prevedini G, Sanchez B, Margolles A, Elviri L, Franco B, van Sinderen D, Ventura M (2015) Evidence for cholesterol-lowering activity by Bifidobacterium bifidum PRL2010 through gut microbiota modulation. Appl Microbiol Biotechnol 99:6813-6829. 
Zhang, CH, Zhang MH, Wang SY, Han RJ, Cao YF, Hua WY, Mao YJ, Zhang XJ, Pang XY, Wei CC, Zhao GP, Chen Y, Zhao LP (2010) Interactions between gut microbiota, host genetics and diet relevant to development of metabolic syndromes in mice. ISME J 4:232241.

Zhang DD, Wang Y, Zheng D, Guo P, Cheng W, Cui ZJ (2016) New combination of xylanolytic bacteria isolated from the lignocellulose degradation microbial consortium XDC2 with enhanced xylanase activity. Bioresour Technol 221:686-690. 
Fig. 1: AXOS/XOS hydrolysates assimilation in $\mathrm{pH}$-controlled batch cultures for donor 1 at time $0 \mathrm{~h}, 4 \mathrm{~h}$ and $8 \mathrm{~h}$ after fermentation. X1, X2, X3, X4, X5, X6 are xylose, xylobiose and xylotriose, xylotetraose, xylopentaose and xylohexose respectively. XA3XX is $3^{3}-\alpha-\mathrm{L}-$ arabinofuranosyl-xylotetraose. At $24 \mathrm{~h}$ there was no detectable sugar remaining in all the culture samples.

Fig. 2: Some of the bacterial populations analysed by Flow-FISH in batch cultures containing different substrates: Error bars indicate SD $(n=3)$. Significant differences between substrates at the same time point are indicated with letters $(P<0.05)$.

Asterisks indicate significantly different compared to $0 \mathrm{~h}$ within the same substrate $(P<0.05)$. 2-way ANOVA with Tukey's post hoc tests were used for the statistical analysis.

Fig. 3: Total SCFAs and acetic concentrations (mM) obtained in $\mathrm{pH}$ controlled batch cultures at $0,4,8$ and $24 \mathrm{~h}$ of fermentation of different substrates. Error bars indicate SD $(n=3)$. Significant differences between substrates at the same time point are indicated with letters. Asterisks indicate significantly different compared to $0 \mathrm{~h}$ within the same substrate * $(P<0.05), * *(P<0.01)$ and $* * *(P<0.001)$. 2-way ANOVA with Tukey's post hoc tests were used for the statistical analysis.

Fig. 4: $\mathrm{AXOS} / \mathrm{XOS}$ fractions $(\mathrm{DP} \geq 3)$ assimilation in $\mathrm{pH}$-controlled batch cultures immediately after inoculation (Time $0 \mathrm{~h}$ ) and after $8 \mathrm{~h}$ and $24 \mathrm{~h}$ of fermentation. X3, X4, X5 and X6 are xylotriose, xylotetraose, xylopentaose and xylohexose respectively. XA3XX is $3^{3}$ $\alpha$-L-arabinofuranosyl-xylotetraose.

Fig. 5: Bifidobacterium abundance along the fermentation under different substrates: NC (Negative control), FOS (positive control), commercial XOS (Longlive Bio-Technology, Shandong, China) and AXOS fractions DP $\geq 3$ obtained from DDGS. Error bars indicate SD $(n=3)$. Significant differences between substrates at the same time point are indicated with letters. 2-way ANOVA with Tukey's post hoc tests were used for the statistical analysis. 
Table 1. Description of enzymatically produced and purified AXOS/XOS

\begin{tabular}{|c|c|c|}
\hline Sample & Treatment & Composition $(\%, w / w)$ \\
\hline DDGS-Xyl & $\begin{array}{c}\text { Deproteinised DDGS } \\
\text { subjected to enzymatic } \\
\text { hydrolysis with GH11 endo- } \\
\text { xylanase }\end{array}$ & $\begin{array}{l}\text { Mixture of xylose (47\%), } \\
\text { XOS (DP2-DP6, 36.3\%) and } \\
\text { AXOS (XA3XX, 2.4\%) }\end{array}$ \\
\hline DDGS-Xyl+FAE & $\begin{array}{c}\text { Deproteinised DDGS } \\
\text { subjected to enzymatic } \\
\text { hydrolysis with GH11 endo- } \\
\text { xylanase and feruloyl } \\
\text { esterase }\end{array}$ & $\begin{array}{c}\text { Mixture of xylose }(33.5 \%) \\
\text { XOS (DP2-DP6, 46\%) and } \\
\text { AXOS (XA3XX, 5.4\%) }\end{array}$ \\
\hline WS-Xyl & $\begin{array}{l}\text { Deproteinised wet solids } \\
\text { subjected to enzymatic } \\
\text { hydrolysis with GH11 endo- } \\
\text { xylanase }\end{array}$ & $\begin{array}{c}\text { Mixture of xylose }(30 \%), \\
\text { XOS (DP2-DP6, 41.4\%) and } \\
\text { AXOS (XA3XX, 4.5\%) }\end{array}$ \\
\hline WS_Xyl+FAE & $\begin{array}{l}\text { Deproteinised wet solids } \\
\text { subjected to enzymatic } \\
\text { hydrolysis with GH11 endo- } \\
\text { xylanase and feruloyl } \\
\text { esterase }\end{array}$ & $\begin{array}{c}\text { Mixture of xylose (31\%), } \\
\text { XOS (DP2-DP6, 31.3\%) and } \\
\text { AXOS (XA3XX, 3.1\%) }\end{array}$ \\
\hline DDGS AXOS/XOS DP $\geq 3$ & $\begin{array}{c}\text { Deproteinised DDGS } \\
\text { subjected to enzymatic } \\
\text { hydrolysis with GH11 endo- } \\
\text { xylanase and feruloyl } \\
\text { esterase and fractionated by } \\
\text { gel filtration }\end{array}$ & $\begin{array}{c}\text { Mixture of XOS (DP3-DP6, } \\
59.3 \% \text { ) and AXOS (XA3XX, } \\
40.5 \%)\end{array}$ \\
\hline
\end{tabular}


Table 2: 16S rRNA-targeted oligonucleotide probes used in this work.

\begin{tabular}{|c|c|c|c|}
\hline $\begin{array}{l}\text { Probe } \\
\text { name }\end{array}$ & Sequence (5' to 3') & Targeted bacterial group & References \\
\hline Non Eub & ACTCCTACGGGAGGCAGC & Negative control & $\begin{array}{l}\text { (Wallner et al. } \\
1993 \text { ) }\end{array}$ \\
\hline Eub338 & GCTGCCTCCCGTAGGAGT & Total bacteria & $\begin{array}{l}\text { (Daims et al. } \\
\text { 1999) }\end{array}$ \\
\hline Eub338II & GCAGCCACCCGTAGGTGT & Total bacteria & $\begin{array}{l}\text { (Daims et al. } \\
\text { 1999) }\end{array}$ \\
\hline Eub338III & GCTGCCACCCGTAGGTGT & Total bacteria & $\begin{array}{l}\text { (Daims et al. } \\
\text { 1999) }\end{array}$ \\
\hline Bif164 & CATCCGGCATTACCACCC & Bifidobacterium spp. & $\begin{array}{l}\text { (Langendijk et } \\
\text { al. 1995) }\end{array}$ \\
\hline Lab158 & GGTATTAGCAYCTGTTTCCA & Lactobacillus/Enterococcus & $\begin{array}{l}\text { (Harmsen et al. } \\
\text { 1999) }\end{array}$ \\
\hline Bac303 & CCAATGTGGGGGACCTT & Bacteroides/Prevotella & $\begin{array}{l}\text { (Manz et al. } \\
1996)\end{array}$ \\
\hline Erec482 & GCTTCTTAGTCARGTACCG & $\begin{array}{l}\text { Eubacterium } \\
\text { rectale/Clostridium cocoides } \\
\text { (Clostridium cluster IVXa } \\
\text { and IVXb) }\end{array}$ & $\begin{array}{l}\text { (Franks et al. } \\
1998 \text { ) }\end{array}$ \\
\hline Rrec584 & TCAGACTTGCCGYACCGC & Roseburia spp. & $\begin{array}{l}\text { (Walker et al. } \\
\text { 2005) }\end{array}$ \\
\hline Ato291 & GGTCGGTCTCTCAACCC & Atopobium cluster & $\begin{array}{l}\text { (Harmsen et al. } \\
2000)\end{array}$ \\
\hline Prop853 & ATTGCGTTAACTCCGGCAC & Clostridium Cluster IX & $\begin{array}{l}\text { (Walker et al. } \\
\text { 2005) }\end{array}$ \\
\hline Fprau655 & CGCCTACCTCTGCACTAC & Faecalibacterium prausnitzii & $\begin{array}{l}\text { (Devereux et } \\
\text { al. 1992) }\end{array}$ \\
\hline DSV687 & TACGGATTTCACTCCT & Desulfovibrio spp. & $\begin{array}{l}\text { (Hold et al. } \\
\text { 2003) }\end{array}$ \\
\hline Chis 150 & TTATGCGGTATTAATCTYCCTTT & $\begin{array}{l}\text { Clostridium histolyticum } \\
\text { (Clostridium cluster I and II) }\end{array}$ & $\begin{array}{l}\text { (Franks et al. } \\
\text { 1998) }\end{array}$ \\
\hline
\end{tabular}


Table 3: SCFAs and lactate concentrations (mM) obtained at $0,8 \mathrm{~h}$ and $24 \mathrm{~h}$ of fermentation in mini-batch cultures. Substrates utilised were: NC (Negative control), FOS (positive control), commercial XOS (Longlive Bio-Technology, Shandong, China) and AXOS/XOS fractions DP $\geq 3$.

\begin{tabular}{llllll}
\hline \multirow{2}{*}{ Acid } & Time & NC & FOS & XOS & $\begin{array}{l}\text { AXOS/XOS DP } \\
\geq \mathbf{3}\end{array}$ \\
\hline Lactic & $0 \mathrm{~h}$ & $3.99(2.32) \mathrm{a}$ & $3.44(0.45) \mathrm{a}$ & $3.65(0.20) \mathrm{a}$ & $4.09(0.04) \mathrm{a}$ \\
& $8 \mathrm{~h}$ & $12.78(3.05) \mathrm{a}$ & $26.96(1.16) \mathrm{a}$ & $26.58(12.59) \mathrm{a}$ & $12.37(2.32) \mathrm{a}$ \\
Formic & $24 \mathrm{~h}$ & $5.00(1.96) \mathrm{a}$ & $8.77(7.99) \mathrm{a}$ & $10.16(9.96) \mathrm{a}$ & $9.28(6.16) \mathrm{a}$ \\
& $0 \mathrm{~h}$ & $2.75(1.83) \mathrm{a}$ & $2.06(0.00) \mathrm{a}$ & $2.77(0.64) \mathrm{a}$ & $1.77(0.00) \mathrm{a}$ \\
& $8 \mathrm{~h}$ & $2.05(2.86) \mathrm{a}$ & $12.97(4.45) \mathrm{a}^{*}$ & $18.77(6.41) \mathrm{a}$ & $8.08(4.95) \mathrm{a}$ \\
Acetic & $24 \mathrm{~h}$ & $2.05(3.02) \mathrm{a}$ & $6.20(6.72) \mathrm{a}^{*}$ & $11.95(6.55) \mathrm{a}$ & $0.65(2.32) \mathrm{a}$ \\
& $0 \mathrm{~h}$ & $2.35(1.32) \mathrm{a}$ & $5.80(6.13) \mathrm{a}$ & $5.54(1.00) \mathrm{a}$ & $5.60(0.03) \mathrm{a}$ \\
Propionic & $8 \mathrm{~h}$ & $12.77(2.95) \mathrm{a}$ & $66.51(4.94) \mathrm{b}^{*}$ & $68.89(4.10) \mathrm{b}^{*}$ & $32.03(13.83) \mathrm{ab}$ \\
& $24 \mathrm{~h}$ & $22.67(2.83) \mathrm{a}$ & $69.74(9.71) \mathrm{b}^{*}$ & $72.45(15.92) \mathrm{b}^{*}$ & $59.55(1.94) \mathrm{ab}$ \\
& $8 \mathrm{~h}$ & $9.56(1.95)$ & $6.42(3.00)$ & $8.30(1.50)$ & $8.69(0.06)$ \\
Butyric & $24 \mathrm{~h}$ & $5.02(3.01) \mathrm{a}$ & $9.58(0.86) \mathrm{a}$ & $11.03(0.68) \mathrm{a}$ & $10.59(0.57) \mathrm{a}$ \\
& $0 \mathrm{~h}$ & $4.64(3.8) \mathrm{a}$ & $10.16(2.54) \mathrm{ab}$ & $9.29(3.05) \mathrm{a}$ & $18.80(1.21) \mathrm{b}^{*}$ \\
& $8 \mathrm{~h}$ & $2.60(1.75) \mathrm{a}$ & $4.77(2.5) \mathrm{a}$ & $4.88(0.1) \mathrm{a}$ & $1.58(0.1) \mathrm{a}$ \\
Total SCFAs & $0 \mathrm{~h}$ & $23.27(5.66) \mathrm{a}$ & $20.60(15.13) \mathrm{a}$ & $20.68(15.13) \mathrm{a}$ & $20.87(0.05) \mathrm{a}$ \\
& $8 \mathrm{~h}$ & $32.99(17.77) \mathrm{a}$ & $120.78(0.08) \mathrm{bc} *$ & $130.14(4.65) \mathrm{c}^{*}$ & $64.12(21.66) \mathrm{ab}$ \\
& $24 \mathrm{~h}$ & $43.48(12.27) \mathrm{a}$ & $108.25(0.69) \mathrm{b}^{*}$ & $116.86(12.19) \mathrm{b}^{*}$ & $92.68(0.95) \mathrm{b}$ \\
\hline
\end{tabular}

Standard deviation is shown in parentheses $(n=3)$. 2-way ANOVA with Tukey's post hoc tests were used for the statistical analysis. Significant differences $(P<0.05)$ among treatment at the same time point are indicated with different letters. (*) Significant difference from $0 \mathrm{~h}$ value, $(P<0.05)$. 
Fig. 1

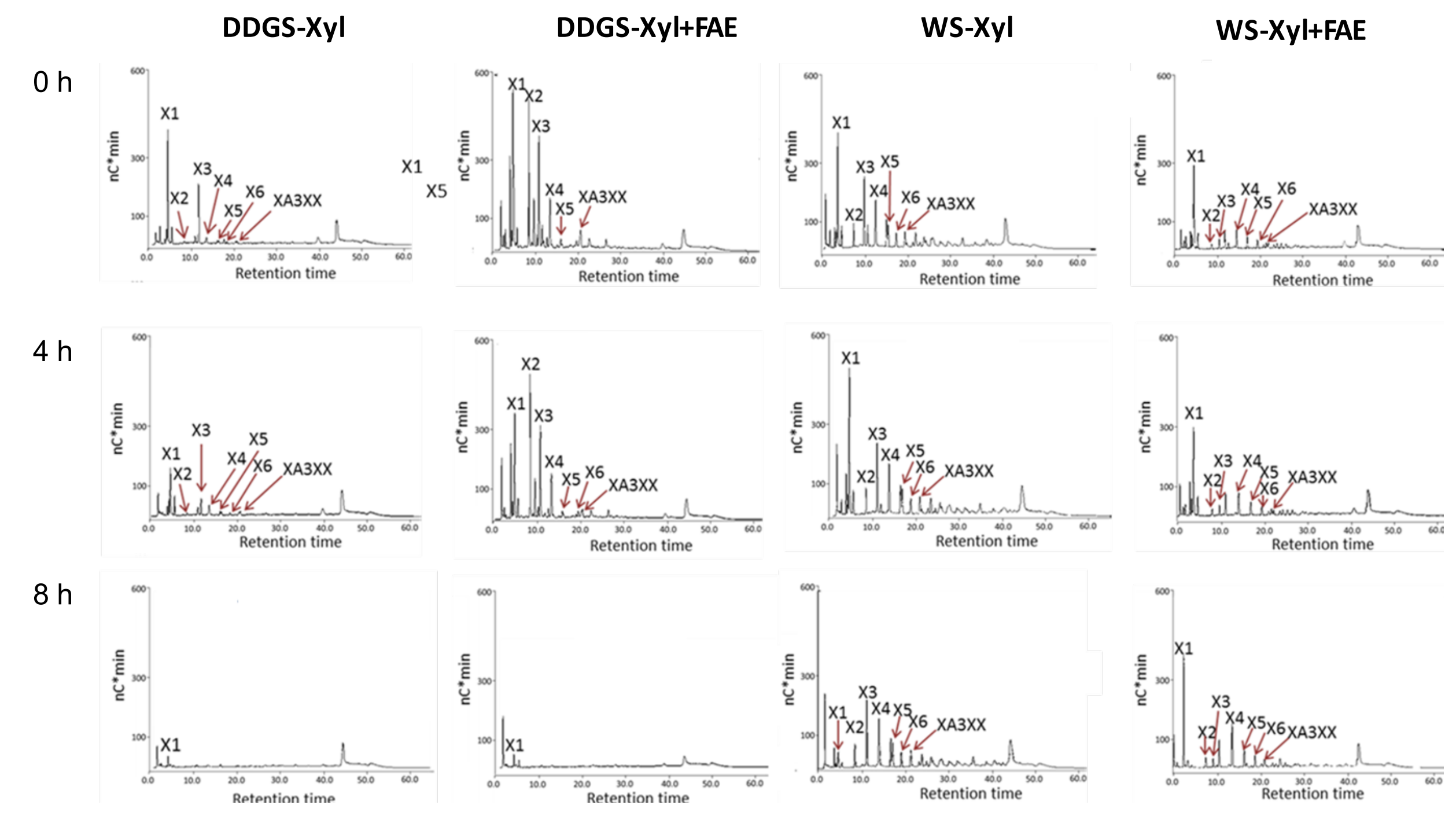


Fig. 2
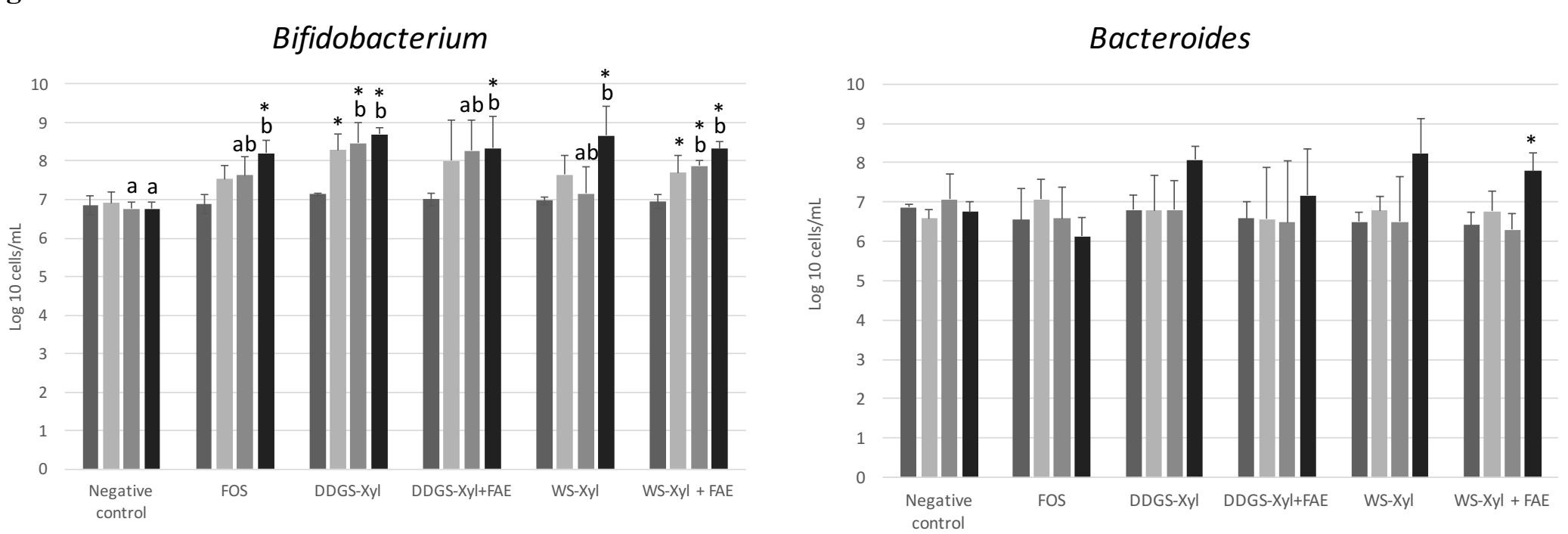

- Time 0

- Time 4

- Time 8

- Time 24
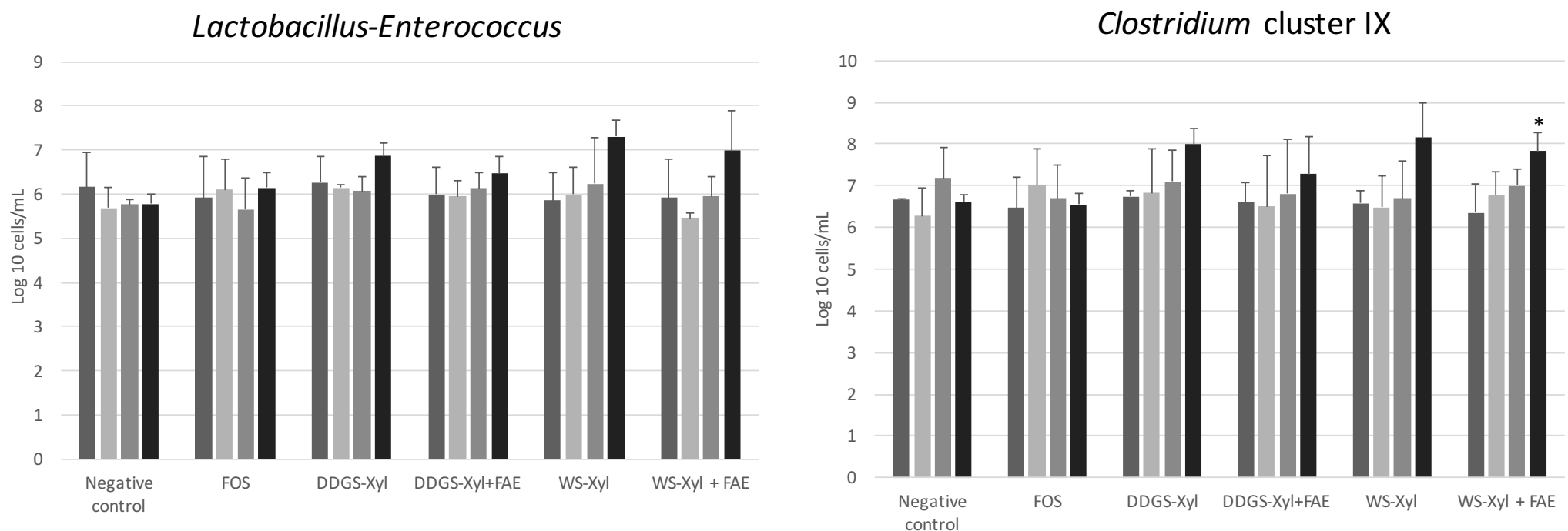
Fig. 3
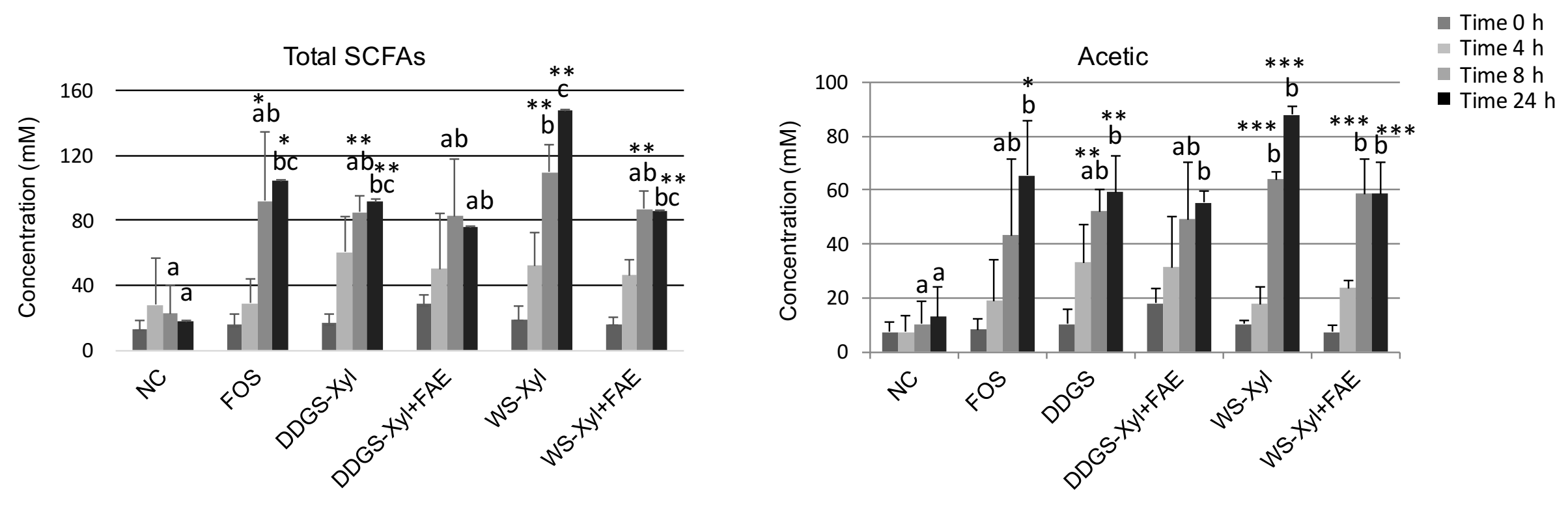
Fig. 4

Commercial XOS
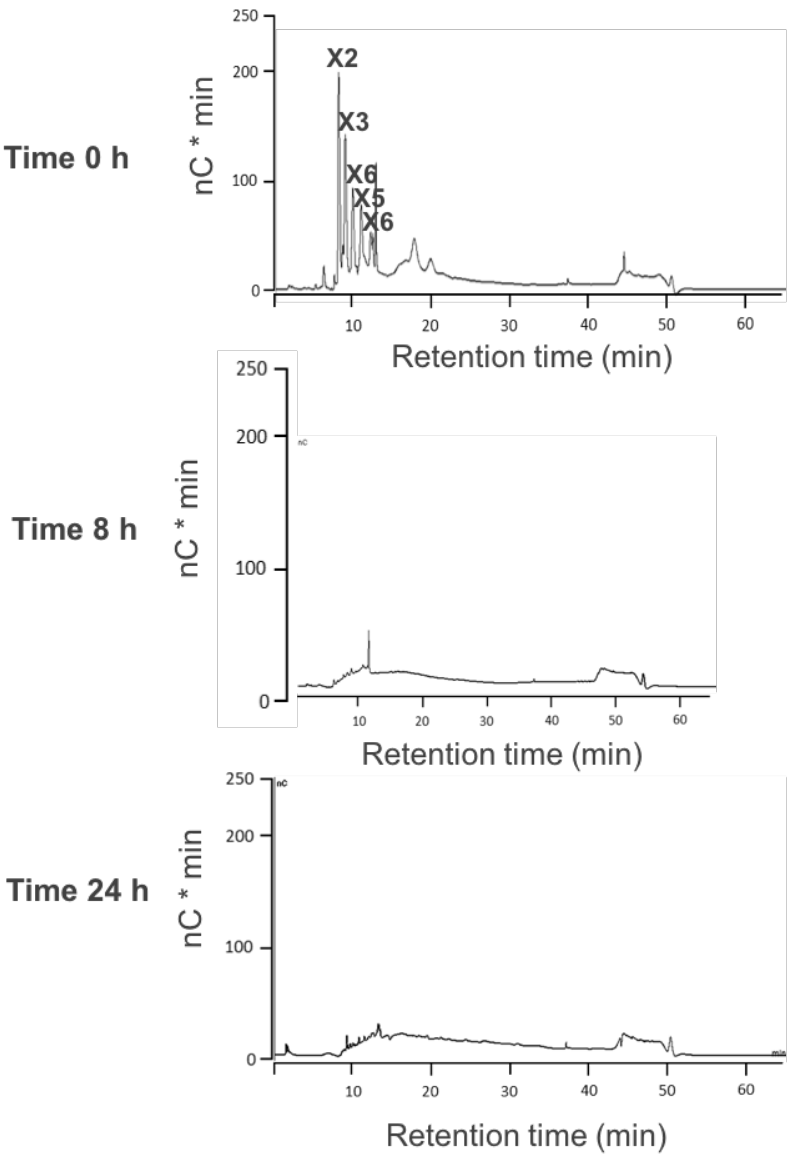

AXOS/XOS DP $\geq 3$
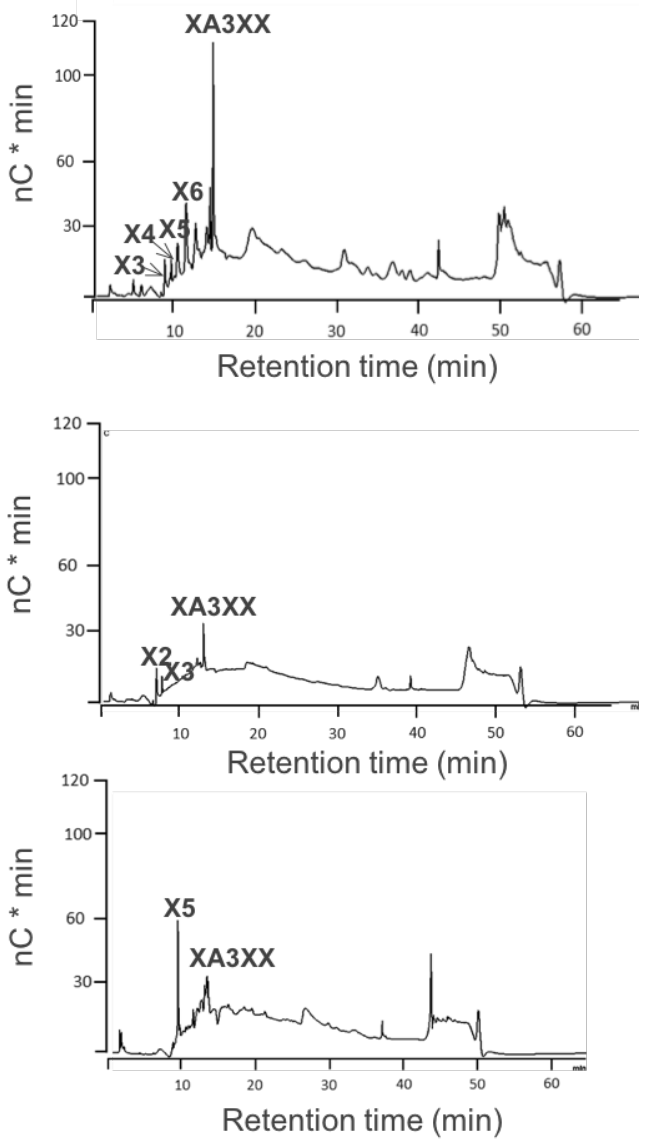
Fig. 5

\section{Bifidobacterium}

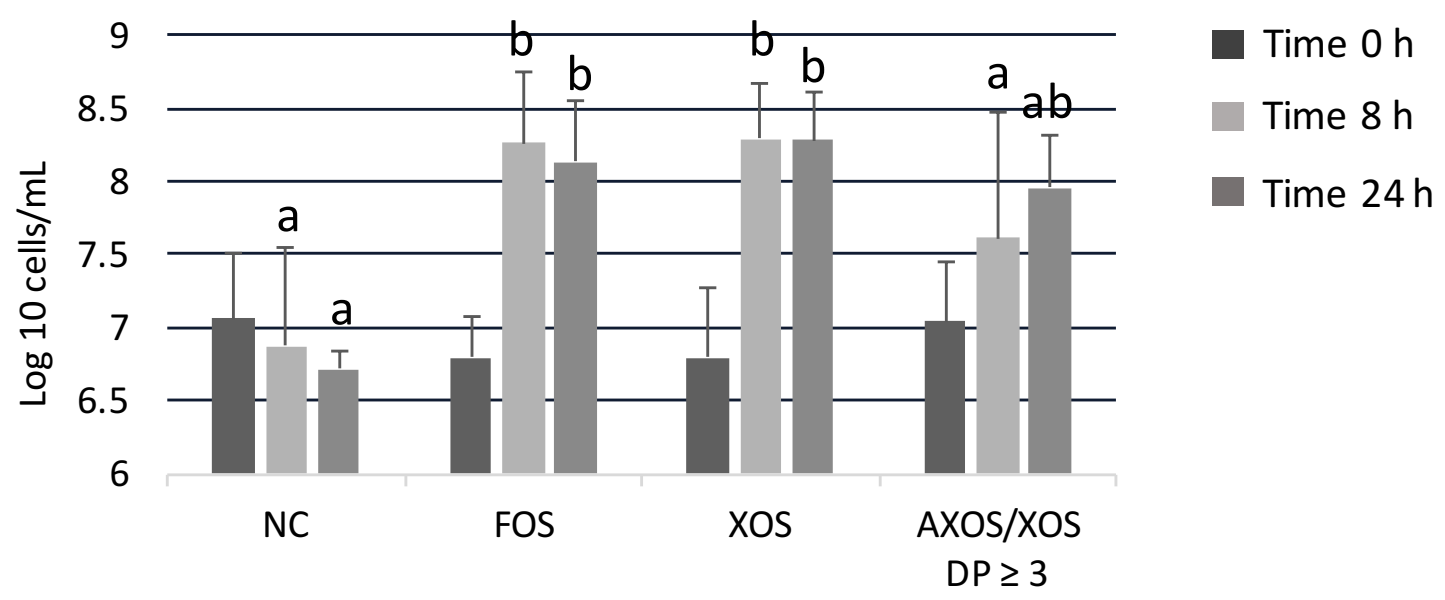

